\title{
WILLIAM CALLYHAN ROBINSON, LL D.
}

To every student at the Yale Law School from its reorganization in 1869 until Professor Robinson's resignation in 1895 , he was well known, and by all beloved.

His grave and handsome face, his extraordinary ability as a teacher, his fluency of speech and masterly diction, his versatility, and his faithfulness to the task of building up the school, made an indelible impression upon his students and his associates, and his death, on November 6th, I9rI, will be mourned by all of them who survive him.

Professor Robinson was in his 78 th year. He graduated at Dartmouth College in 1854 , and received from her the degree of LL.D. in I879. In I857 he graduated at the General Theological Seminary and until 1862 was a clergyman of the Protestant Episcopal Church at Pittston, and later at Scranton, in the State of Pennsylvania. In I864 he was admitted to the Bar in Luzerne County, Pennsylvania. He practiced at New Haven from I865 to I895, and served on the Bench in two of the inferior courts.

When, after the death of its last Professor in 1869 , the very existence of the Yale Law School seemed to be doomed, three members of the New Haven County Bar: Messrs. Simeon E. Baldwin, William C. Robinson and Johnson T. Platt, with the encouragement of President Woolsey, undertook, at their own risk, the task of building up and carrying on the school. Later Mr. Francis Wayland became associated with them and was made Dean of the school.

What success attended their faithful and unselfish efforts need not be told here.

In I895 Prof. Robinson resigned to accept the position of Dean of the Law School of the Catholic University of America, and he retained it to the time of his death.

Through his works, notably those on Elementary Law, Patents and Forensic Oratory, he was well known to many students and practitioners; who were beyond the scope of his personal influence.

Five children survive him; two of whom, George W. Robinson and Philip N. Robinson, are graduates of the Yale Law School. 


\section{$\checkmark$}

